\title{
Impaired reproduction in the amphipods Monoporeia affinis and Pontoporeia femorata as a result of moderate hypoxia and increased temperature
}

\author{
Ann-Kristin Eriksson Wiklund*, Brita Sundelin \\ Institute of Applied Environmental Research, Stockholm University, 10691 Stockholm, Sweden
}

\begin{abstract}
Laboratory experiments were performed on the amphipods Monoporeia affinis and Pontoporeia femorata in order to test the hypotheses that specific reproductive variables are affected by moderate hypoxia and/or slightly increased temperature. These reproductive variables include unfertilised/undeveloped eggs, dead eggs and females carrying a dead brood. In a series of experiments, amphipods were exposed to increased temperature during different parts of the reproduction cycle. Exposure prior to mating caused an increased number of dead eggs and a higher percentage of females carrying dead broods. Furthermore, the effects of low oxygen concentrations ( 2 to $6 \mathrm{mg} \mathrm{O}_{2} \mathrm{l}^{-1}$ ), solely and in combination with contaminated sediments, heavy metals and hydrophobic organic contaminants (polycyclic aromatic hydrocarbons and polychlorinated biphenyls), were tested during the reproduction cycle. Exposure to low oxygen concentrations induced a higher frequency of females carrying dead broods, and females exposed to hypoxia or contaminants had a lower fertility rate compared to controls. Our results show that oxygen concentrations and temperature conditions normally occurring in the Baltic Sea and that are not otherwise detrimental to adults could severely affect the gonads and the embryos. Females with dead broods, undeveloped/unfertilised eggs and dead eggs are proposed as tools for use in monitoring non-contaminant stressors.
\end{abstract}

KEY WORDS: Reproduction · Temperature $\cdot$ Hypoxia $\cdot$ Monitoring $\cdot$ Amphipods $\cdot$ Monoporeia affinis Pontoporeia femorata

Resale or republication not permitted without written consent of the publisher

\section{INTRODUCTION}

Monoporeia affinis and Pontoporeia femorata (Amphipoda: Crustacea) are both important inhabitants of the Baltic macrofauna community. M. affinis is considered to be a key species in structuring benthic communities (Lopez \& Elmgren 1989). The species have different origins and geographical distributions: $M$. affinis is a glacial relict, found in lakes below the highest coastline and in the Baltic; P. femorata is a marine species, seldom found north of the southern Bothnian Sea due to the salinity gradient in the Baltic. In the Baltic proper, both species co-occur and feed on the

*E-mail: annkristin.eriksson@itm.su.se top surface sediment layer (Lopez \& Elmgren 1989). They differ however in depth distribution, and a larger proportion of $P$. femorata is found deeper in the sediment than $M$. affinis, although more than $80 \%$ of both species is found in the top $5 \mathrm{~cm}$ (Hill \& Elmgren 1987).

The life cycles of the 2 species are similar. In shallow waters (less than 15 to $20 \mathrm{~m}$ ), Monoporeia affinis usually has a $1 \mathrm{yr}$ life cycle although in the Baltic proper at depths where the species is most frequent $(20$ to $50 \mathrm{~m})$ the life cycle is $2 \mathrm{yr}$, whereas Pontoporeia femorata has a 2 yr life cycle at least down to $45 \mathrm{~m}$ (Cederwall 1978). At greater depth, both species have a 3 yr life cycle. The reproduction cycle starts at the beginning of August and is triggered by the reduction in light (Segerstråle 1971). The gonads mature during the 
autumn and mating starts in the beginning of November, after which males die within some weeks (Sundelin \& Eriksson 1998). However, deviations from the seasonal reproduction cycle have been observed for both species. Sexually mature adults, both male and female, have been noticed at times other than the normal reproduction season (Eriksson et al. 1999).

Several studies in contaminated areas have demonstrated the usefulness of Monoporeia affinis reproduction variables in monitoring effects of xenobiotics in the field (Elmgren et al. 1983, Sundelin \& Eriksson 1998). The embryonic development of the amphipod was found to be particularly sensitive to exposure to various contaminants and the frequency of malformed embryos is used as a biomarker in the Swedish National Monitoring Programme for monitoring effects of contaminated sediments. Besides malformed embryos, other deviations from normal development have been observed, i.e. unfertilised/undeveloped and dead eggs and embryos, and females with dead broods in their marsupium (brood chamber) (Sundelin \& Eriksson 1998, Andersson et al. 1999). However, these variables were not correlated with pollution gradients in industrial recipients (Sundelin \& Eriksson 1998).

The occurrence of dead eggs and females carrying dead broods is more common in the Baltic proper, than in Bothnian Bay (Andersson et al. 2000). Due to higher eutrophication level, hypoxia and hydrogen sulphides occur more frequently in the Baltic proper sediments than in those of the Bothnian Sea (Andersson et al. 2000, Kajrup 2000). Thus, we hypothesise that dead eggs and females carrying a dead brood result mainly from hypoxia and not from contaminants. We also have indications that unfertilised/undeveloped eggs are more common following autumns with higher water temperatures (unpubl. data). In a series of experiments, we examined the effect of natural environmental variables such as temperature and oxygen on different reproductive processes. The aim was to: (1) de-

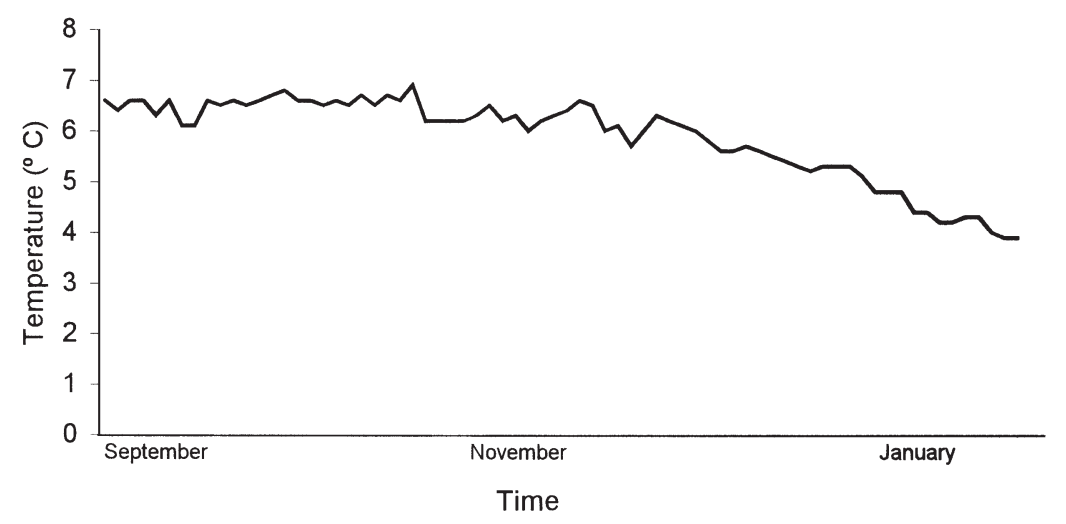

Fig. 1. Temperature of incoming water in flow-through microcosm used in experiments velop tools for monitoring the effects of natural environmental as well as climate variables, and (2) evaluate the possibility of differentiating anomalies caused by stressors such as hypoxia from those caused by contaminants.

\section{MATERIAL AND METHODS}

Sampling and experimental set-up. Experiments were performed in the flow-through microcosm system described by Sundelin (1983). Briefly, the microcosm system consists of 21 Ehrlenmeyer flasks (bottom area $227 \mathrm{~cm}^{2}$ ). The water inlet is placed below the outlet to produce a natural flow of water and to minimise gradients. The flasks were wrapped in green plastic to simulate the wavelength in situ, and a timer regulated light to natural day-length. The incoming water from $37 \mathrm{~m}$ depth (salinity $7 \%$ ) was filtered through a $280 \mu \mathrm{m}$ net to avoid predator larvae, and followed the natural seasonal regime (Fig.1). The amphipods were prevented from surface contact by fine nets (mesh size $0.25 \mathrm{~mm}$ ) below the water surface. The temperature in situ has been yearly monitored since the early 1980s. Variation at this depth is very small between years, and follows the same pattern every year. Between 1992 and 1999 the average temperature in the area at $40 \mathrm{~m}$ depth in September has been $5.7 \pm \mathrm{SD} 1.2^{\circ} \mathrm{C}$ and in October $5.8 \pm \mathrm{SD} 1.4^{\circ} \mathrm{C}$ (SHARK database: Swedish Meteorological and Hydrological Institute, Västra Frölunda).

The sediment and amphipods Monoporeia affinis and Pontoporeia femorata used in the experiments were collected with a benthic sled (Blomqvist \& Lundgren 1996) at a reference site near the Askö Laboratory, a Stockholm University field station in the northern Baltic proper. At this site, background levels of both metals and organic contaminants in sediment and amphipods have been recorded (Sundelin \& Eriksson 2001). Amphipods were carefully collected after sieving the sediment through a $1.0 \mathrm{~mm}$ net, and immediately transferred to containers with cool water $\left(4^{\circ} \mathrm{C}\right)$ for further transport to the laboratory. The amphipods were sorted according to species and year-classes (separated by size). To exclude larvae of amphipod predators the sediment was sieved through a $0.5 \mathrm{~mm}$ net.

Biological variables. The adults and embryos were examined in regard to different aberrations (Table 1) from normal development according to Sundelin \& Eriksson (1998). Variables studied for females were fertilisation success, fe- 
Table 1. Monoporeia affinis and Pontoporeia femorata. Female reproductive variables and embryo variables

\begin{tabular}{|c|c|}
\hline Variable & Explanation \\
\hline Fecundity & Eggs per female \\
\hline Fertilised females & $\begin{array}{l}\text { Females carrying fertilised eggs in } \\
\text { brood pouch }\end{array}$ \\
\hline $\begin{array}{l}\text { Females with } \\
\text { dead brood }\end{array}$ & $\begin{array}{l}\text { Females, carrying fat residue in } \\
\text { brood pouch consisting of decom- } \\
\text { posing, dead, and unfertilised eggs. } \\
\text { Residue is homogenous cell mass, in } \\
\text { which single eggs are no longer } \\
\text { identifiable }\end{array}$ \\
\hline $\begin{array}{l}\text { Developmental } \\
\text { stage }\end{array}$ & $\begin{array}{l}\text { Embryo development, divided } \\
\text { into } 9 \text { arbitrary stages, from newly } \\
\text { fertilised egg to hatched juvenile }\end{array}$ \\
\hline Malformed egg & $\begin{array}{l}\text { Fertilised egg showing different } \\
\text { types of aberrations }\end{array}$ \\
\hline $\begin{array}{l}\text { Unfertilised/ } \\
\text { undeveloped egg }\end{array}$ & $\begin{array}{l}\text { Egg that is unfertilised or has } \\
\text { ceased to develop before gastrulation }\end{array}$ \\
\hline Dead egg & $\begin{array}{l}\text { Dead egg that has not decayed } \\
\text { and is thereby still countable }\end{array}$ \\
\hline
\end{tabular}

cundity (eggs/female), and dead brood. Developmental stage and percentage of malformed embryos, unfertilised/undeveloped eggs, dead eggs and dead embryos were recorded (for further details see Sundelin \& Eriksson 1998)

Temperature experiments (Expts 1 and 2). Two experiments were carried out to examine the effect of increased temperature on reproduction. To each aquarium we added $400 \mathrm{ml}$ of sediment (water content $70 \%$ ) and 50 sub-adult amphipods (1+yr). A sex ratio of 1:1 was expected (Segerstråle 1937); this has been checked regularly by the authors over several years (1985 to 2000, unpubl. data). To increase the water temperature, test aquaria were supplied with water from tanks equipped with a heater and a thermostat; temperatures in the aquaria and tanks were checked daily. Expt 1 started in early September, during the period of gonad maturation, and was terminated in November, when mating occurs. Expt 2 started at the same time in September, but was terminated in January when embryogenesis has lasted for about 2 mo. Expt 1 was performed on Monoporeia affinis, while Expt 2 included both $M$. affinis and Pontoporeia femorata.

Expt 1 included 10 replicates for each of 3 experimental conditions: (1) control (temperature of incoming water unchanged), and temperature raised by (2) $3.2^{\circ} \mathrm{C}$ and (3) $5.4^{\circ} \mathrm{C}$. After termination of the experiment in November, the number of fertilised and unfertilised females in each microcosm was counted.

Expt 2 comprised 3 series: (1) control, in which incoming water followed the natural temperature regime; (2) temperature of incoming water raised during gonad maturation, before mating; (3) temperature raised after the mating period, i.e. during embryogenesis. The temperature was increased by $3.2 \pm 0.2^{\circ} \mathrm{C}$. Each series included 5 replicates.

Oxygen experiment (Expt 3). Decreased oxygen concentrations were tested in combination with contaminated sediments, resulting in 4 series: (1) control, high oxygen concentration; (2) low oxygen concentration; (3) low oxygen concentration in combination with contaminated sediment; (4) high oxygen concentration in combination with contaminated sediment. To each aquarium we added $400 \mathrm{ml}$ of sediment (water content $70 \%)$ and 50 sub-adult amphipods (1+yr), and 5 replicates of each series were included. The experiment was only performed on Monoporeia affinis, due to low abundance of Pontoporeia femorata in the field, which caused collecting difficulties. The experiment started in September and ended in January.

Low oxygen concentrations were generated by lowering the incoming water-flow to the microcosms from

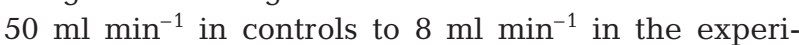
ments. The original oxygen concentration $\left(8 \mathrm{mg} \mathrm{O}_{2} \mathrm{l}^{-1}\right)$ was gradually reduced over 2 wk by lowering the water flow. The average oxygen concentration in the low oxygen incubation series was $3.6 \pm 1.3(\mathrm{SD}) \mathrm{mg} \mathrm{O}_{2}$ $\mathrm{l}^{-1}$, ranging from 2 to $4.5 \mathrm{mg} \mathrm{O}_{2} \mathrm{l}^{-1}$ (2 to $6 \mathrm{mg} \mathrm{O}_{2} \mathrm{l}^{-1}$ when the first weeks of acclimation are included). Oxygen concentration in the high-oxygen series ranged from 7.5 to $11 \mathrm{mg} \mathrm{O} \mathrm{I}^{-1}$ with an average of $9.7 \pm \mathrm{SD} 1.4 \mathrm{mg} \mathrm{O}_{2} \mathrm{l}^{-1}$. This procedure was an attempt to mimic the natural variation in situ. The oxygen concentration was measured daily by a portable oxygen meter (WTW Oxi 323-B, Welheim, Germany) according to SS-EN 25813 (SIS 1993a) and SS-EN 25814 (SIS 1993b). In Series 3 and 4, $150 \mathrm{ml}$ contaminated sediment was added to $250 \mathrm{ml}$ control sediment, resulting in the same sediment volume as in the non-contaminant series. Contaminated sediment formed the surface sediment layer, where amphipods feed. This sediment was collected from Stockholm harbour and was contaminated by trace metals and persistent hydrophobic contaminants, e.g. polycyclic aromatic hydrocarbons (PAHs) and polychlorinated biphenyls (PCBs) (for details see Sundelin \& Eriksson 2001). Toxicity of the settling sediment material and sediment at sampling site has been shown by Ishaq et al. 1999 and Sundelin \& Eriksson 2001).

Statistical evaluation. Data from Expts 1 and 2 were evaluated by a 2-way analysis of variance, with temperature and species as factors. Data from Expt 3 were analysed by analyses of variance followed by a Dunnett post hoc procedure. The analyses were based on mean values per replicate with a logistic transformation, $\log _{10}[x /(1-x)]$, applied to the data prior to the analyses. Since low fertilisation in the oxygen experiment resulted in loss of replicates for the embryo 


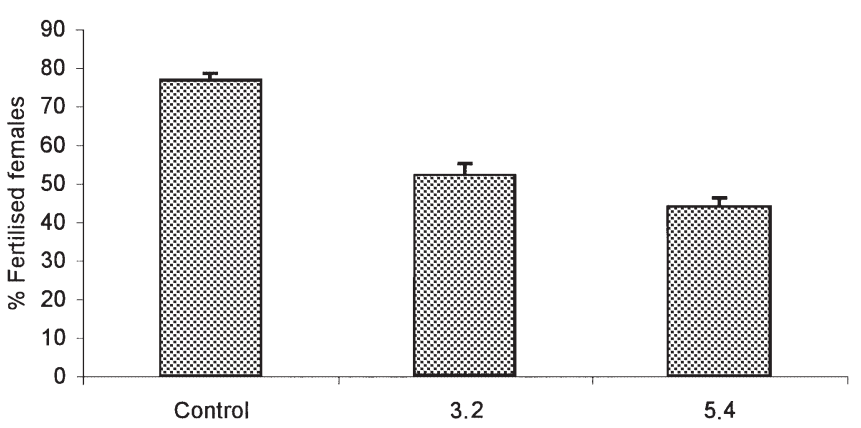

Fig. 2. Monoporeia affinis. Expt 1. Percent fertilised females exposed before mating to 3 temperatures: control (temperature unchanged), temperature increased by $3.2^{\circ} \mathrm{C}$ and temperature increased by $5.4^{\circ} \mathrm{C}$. Data are based on mean values of 10 replicates and error bars represent $95 \%$ confidence interval analyses, calculations were based on total number of eggs in each series, and differences between proportions were compared according to Zar (1984, p. 400-404). For multiple comparisons between control and treatments we used a Dunnett-type post hoc procedure with arcsine-transformed proportions (Zar 1984). In all statistical evaluations, the conventional significance level of $\alpha=0.05$ was applied.

\section{RESULTS}

\section{Temperature experiments (Expts 1 and 2)}

In Expt 1, the proportion of fertilised females Monoporeia affinis decreased significantly with increasing temperature prior to mating (Fig. 2).

Table 2. Monoporeia affinis and Pontoporeia femorata. Expt 2. Statistical parameters of 2-way ANOVAs. Tests were performed for differences between species (factor $=$ species), for an effect of temperature across both species (factor $=$ temperature) and for a difference in the effect of temperature between the 2 species (factor $=$ species $\times$ temperature). In addition, tests were designed to compare the effect of temperature specifically for Monoporeia affinis and for these comparisons the magnitude of the effect was also estimated (Est.d.) In Pontoporeia femorata large inter-replicate variation, due to low fertilisation success, made the corresponding species-specific comparisons uninformative. ns = not significant

\begin{tabular}{|c|c|c|c|c|}
\hline Dependent variable & Factor & $F$ & Est.d & $\mathrm{p}$ \\
\hline Fertilised females (\%) & $\begin{array}{l}\text { Species } \\
\text { Temperature } \\
\text { Interaction Species } \times \text { Temperature } \\
\text { Control-before } \\
\text { Control_after }\end{array}$ & $\begin{array}{r}83.14 \\
6.37 \\
0.15\end{array}$ & $\begin{array}{r}0.55 \\
-0.12\end{array}$ & $\begin{array}{c}<0.001 \\
0.004 \\
\text { ns } \\
0.006 \\
\text { ns }\end{array}$ \\
\hline Fecundity & $\begin{array}{l}\text { Species } \\
\text { Temperature } \\
\text { Interaction Species } \times \text { Temperature } \\
\text { Control—before } \\
\text { Control_-after }\end{array}$ & $\begin{array}{r}37.45 \\
32.27 \\
6.48\end{array}$ & $\begin{array}{r}22.31 \\
9.08\end{array}$ & $\begin{array}{r}<0.001 \\
<0.001 \\
0.006 \\
<0.001 \\
0.003\end{array}$ \\
\hline Developmental stage & $\begin{array}{l}\text { Species } \\
\text { Temperature } \\
\text { Interaction Species } \times \text { Temperature } \\
\text { Control—before } \\
\text { Control_-after }\end{array}$ & $\begin{array}{r}10.87 \\
1.47 \\
0.36\end{array}$ & $\begin{array}{l}-0.27 \\
-0.62\end{array}$ & $\begin{array}{l}0.004 \\
\text { ns } \\
\text { ns } \\
\text { ns } \\
0.02\end{array}$ \\
\hline Dead broods (\%) & $\begin{array}{l}\text { Species } \\
\text { Temperature } \\
\text { Interaction Species } \times \text { Temperature } \\
\text { Control—before } \\
\text { Control_after }\end{array}$ & $\begin{array}{r}26.43 \\
4.75 \\
4.88\end{array}$ & $\begin{array}{l}-0.79 \\
-0.26\end{array}$ & $\begin{array}{c}<0.001 \\
0.02 \\
0.02 \\
0.02 \\
\text { ns }\end{array}$ \\
\hline Dead eggs $(\%)$ & $\begin{array}{l}\text { Species } \\
\text { Temperature } \\
\text { Interaction Species } \times \text { Temperature } \\
\text { Control—before } \\
\text { Control_-after }\end{array}$ & $\begin{array}{c}0.002 \\
2.62 \\
1.25\end{array}$ & $\begin{array}{l}-1.22 \\
-0.43\end{array}$ & $\begin{array}{l}\text { ns } \\
\text { ns } \\
\text { ns } \\
0.001 \\
\text { ns }\end{array}$ \\
\hline Unfertilised/undeveloped (\%) & $\begin{array}{l}\text { Species } \\
\text { Temperature } \\
\text { Interaction Species } \times \text { Temperature } \\
\text { Control—before } \\
\text { Control_after }\end{array}$ & $\begin{array}{l}4.41 \\
1.18 \\
0.47\end{array}$ & $\begin{array}{l}-0.88 \\
-0.58\end{array}$ & $\begin{array}{l}\text { ns } \\
\text { ns } \\
\text { ns } \\
0.04 \\
\text { ns }\end{array}$ \\
\hline Malformed (\%) & $\begin{array}{l}\text { Species } \\
\text { Temperature } \\
\text { Interaction Species } \times \text { Temperature } \\
\text { Control—before } \\
\text { Control_-after }\end{array}$ & $\begin{array}{r}21.52 \\
2.89 \\
1.97\end{array}$ & $\begin{array}{l}-0.27 \\
-0.29\end{array}$ & $\begin{array}{c}<0.001 \\
\mathrm{~ns} \\
\mathrm{~ns} \\
\mathrm{~ns} \\
\mathrm{~ns}\end{array}$ \\
\hline
\end{tabular}


In Expt 2, the rate of fertilised females also decreased when exposed to increased temperature prior to mating, but to a lesser extent than in Expt 1 (Table 2, Fig 3A). The effect was similar in both species, although statistically significant only for Monoporeia affinis. Examination of the unfertilised female Pontoporeia femorata revealed a considerable difference in gonad development between specimens. We found females with both mature degenerated gonads and females with small immature gonads in which development was delayed by about $2 \mathrm{mo}$; this occurred irrespective of temperature treatment and reduced the number of fertilised $P$. femorata females available for examination.

Increased pre-mating temperature caused a substantial reduction in fecundity in both species, whereas increased post-mating temperature caused but a moderate reduction (Table 2, Fig. 3B). Similar results were obtained whether females with dead broods were included in or excluded from the fecundity calculations. Exposure to raised post-mating temperature resulted in a significantly higher stage of embryo development in Monoporeia affinis (Table 2, Fig. 3C). Pre-mating exposure to increased temperature did not affect embryonic development in either species. Regardless of treatment, fecundity was higher and embryos further developed in M. affinis than in Pontoporeia femorata (Table 2, Fig. 3C).

The proportion of females carrying a dead brood was higher after exposure to increased temperature than in controls (Table 2, Fig. 3D). The effect was statistically significant for pre-mating exposure in Monoporeia affinis (Table 2).

The percentage of dead and undeveloped/unfertilised eggs in Monoporeia affinis was higher when temperature was increased before mating (Table 2,
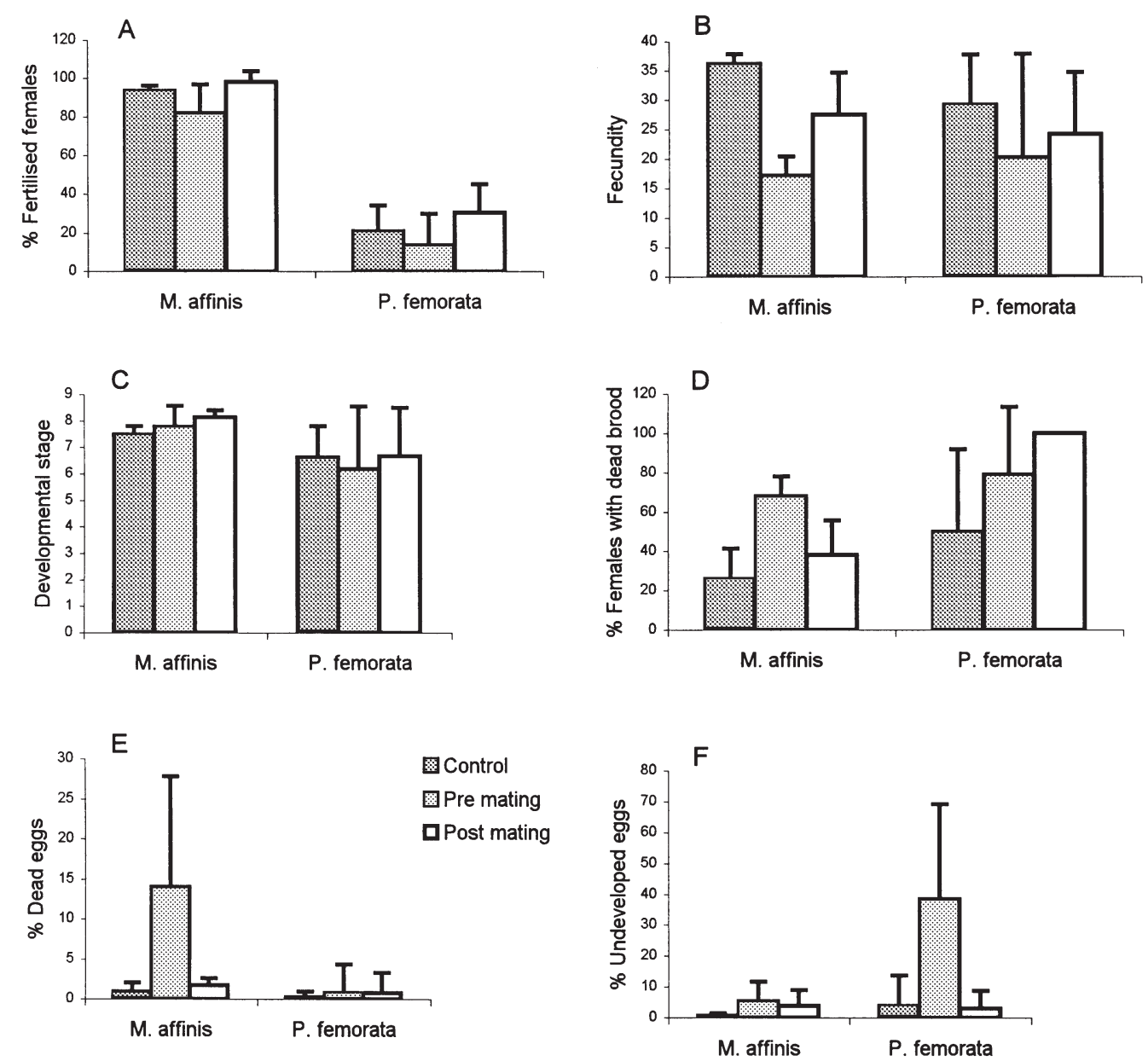

Fig. 3. Monoporeia affinis and Pontoporeia femorata. Expt 2. Amphipods exposed to increased (by $3.2^{\circ} \mathrm{C}$ ) temperature before or after mating. (A) Fertilised females; (B) fecundity (egg/female); (C) embryo developmental stage; (D) \% females with dead brood; (E) \% dead eggs; (F) \% unfertilised/undeveloped eggs. Data are based on mean values of 5 replicates and error bars represent 
Table 3. Monoporeia affinis: Expt 3. Statistical parameters of 1-way ANOVAs and Dunnett-type post hoc procedure. low ox.: low oxygen; cont. sed.: contaminated sediment. Other abbreviations as in Table 2. Insufficient numbers of Pontoporeia femorata were available for analysis because of low abundance in the field

\begin{tabular}{|c|c|c|c|c|}
\hline Dependent variable & Factor & $F$ & Est.d & $\mathrm{p}$ \\
\hline Fertilised females (n) & $\begin{array}{l}\text { Treatment } \\
\text { Control-low oxygen } \\
\text { Control-contaminated sediment } \\
\text { Control-low ox. + cont. sed. }\end{array}$ & 15.49 & $\begin{array}{l}7.20 \\
6.60 \\
5.80\end{array}$ & $\begin{array}{l}<0.001 \\
<0.001 \\
<0.001 \\
<0.001\end{array}$ \\
\hline $\begin{array}{l}\text { Unfertilised/undeveloped } \\
\text { females }(\%)\end{array}$ & $\begin{array}{l}\text { Treatment } \\
\text { Control-low oxygen } \\
\text { Control-contaminated sediment } \\
\text { Control-low ox. + cont. sed. }\end{array}$ & 6.85 & $\begin{array}{l}-2.14 \\
-1.44 \\
-0.79\end{array}$ & $\begin{array}{l}0.007 \\
0.003 \\
\mathrm{~ns} \\
\mathrm{~ns}\end{array}$ \\
\hline Dead brood (\%) & $\begin{array}{l}\text { Treatment } \\
\text { Control-low oxygen } \\
\text { Control-contaminated sediment } \\
\text { Control-low ox. + cont. sed. }\end{array}$ & 7.57 & $\begin{array}{r}-1.31 \\
0.16 \\
-0.82\end{array}$ & $\begin{array}{c}0.004 \\
0.007 \\
\mathrm{~ns} \\
0.046\end{array}$ \\
\hline Fecundity & $\begin{array}{l}\text { Treatment } \\
\text { Control-low oxygen } \\
\text { Control-contaminated sediment } \\
\text { Control-low ox. + cont. sed. }\end{array}$ & 6.42 & $\begin{array}{r}2.82 \\
-3.11 \\
-11.09\end{array}$ & $\begin{array}{l}0.013 \\
\mathrm{~ns} \\
\mathrm{~ns} \\
0.02\end{array}$ \\
\hline
\end{tabular}
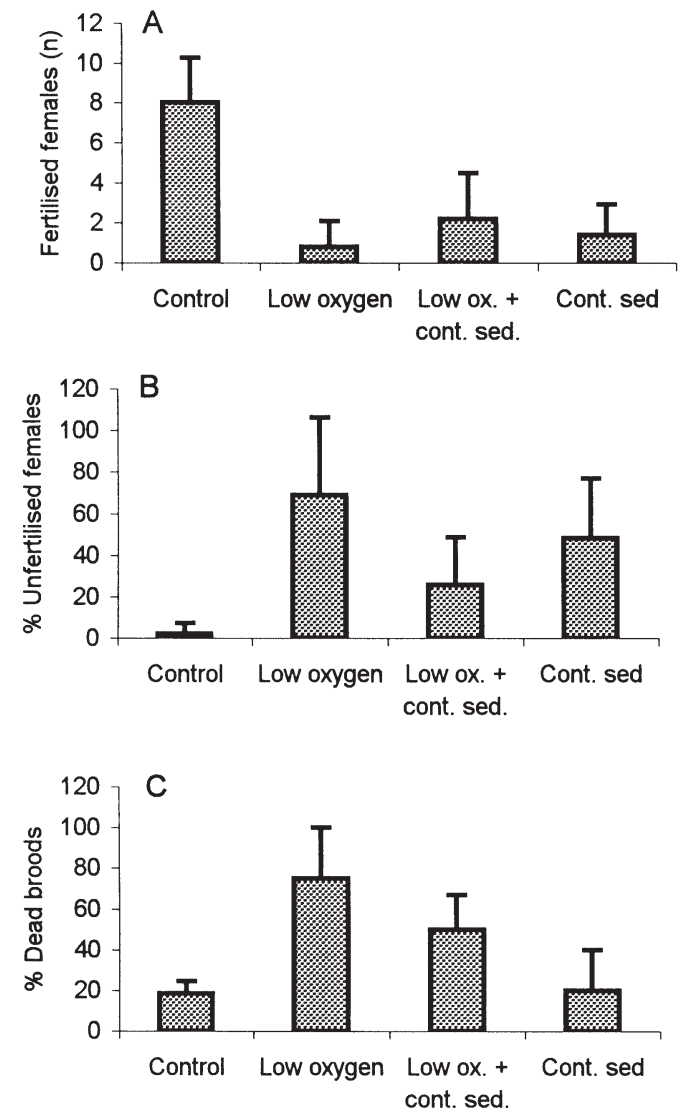

Fig. 4. Monoporeia affinis. Expt 3. Amphipods exposed to moderate hypoxia solely and in combination with contaminated sediment during the reproduction cycle (September to January). (A) Number of fertilised females; (B) \% unfertilised females; (C) \% females with dead brood. Data are based on mean values of 5 replicates and error bars represent SD
Fig. 3E,F). Due to large inter-replicate variation in series with Pontoporeia femorata, the increased percentage of unfertilised/undeveloped eggs was not statistically significant in this species. Finally, increased temperature did not increase the percentage of malformed embryos in either species, although malformations were more frequently in P. femorata (3.4 to $9.4 \%$ ) than in for $M$. affinis (1.9 to $3.8 \%$ ) (Table 2).

\section{Oxygen experiment (Expt 3)}

The number of fertilised female Monoporeia affinis was severely reduced in all treatments compared to control (Table 3, Fig. 4A) and the percentage of unfertilised females was higher (Table 3, Fig. 4B). Furthermore, the number of females with dead broods increased when exposed to reduced oxygen levels during the periods of gonad maturation and embryogenesis. Exposure to contaminated sediment did not further increase this aberration (Table 3, Fig. 4C). Exposure to hypoxia did not affect fecundity, while low oxygen concentrations in combination with contaminated sediment decreased fecundity (Table 3).

Due to a low fertilisation rate, there was only a limited amount of data available for analyses of different embryo aberrations. Nevertheless, the proportion of both malformed and unfertilised/undeveloped eggs was shown to increase compared to controls $(p<0.001)$ (Table 4). The degree of decay among the dead and dying eggs varied considerably, resulting in difficulties in counting the dead eggs. We therefore omitted this variable from the analyses. 
Table 4. Monoporeia affinis. Expt 3. Results and statistical parameters of multiple comparisons (Dunnett-type post hoc procedure), of the variables malformed and unfertilised/undeveloped eggs. In both cases, main effects resulted in $\mathrm{p}<0.001$ after a comparison between proportions (Zar 1984). -: comparison uniformative because mean proportion lower than control

\begin{tabular}{|c|c|c|c|c|}
\hline Parameter & Control & Low $\mathrm{O}_{2}$ conc. & $\begin{array}{c}\text { Low } \mathrm{O}_{2} \text { conc. }+ \\
\text { contaminated sediment }\end{array}$ & $\begin{array}{l}\text { Contaminated } \\
\text { sediment }\end{array}$ \\
\hline Malformed eggs (\%) & 2.8 & 4.7 & 8.6 & 7.8 \\
\hline Transformed proportions & 9.72 & 12.91 & 17.16 & 16.33 \\
\hline SE & & 1.34 & 0.99 & 0.98 \\
\hline Critical $\mathrm{q}_{0.05, \infty, 4}$ & & 2.35 & 2.35 & 2.35 \\
\hline Actual q & & 2.37 & 7.44 & 6.76 \\
\hline Unfertilised/undeveloped eggs (\%) & 1.78 & 5.69 & 5.80 & 0.42 \\
\hline Transformed proportions & 7.6 & 14.17 & 14.06 & 4.31 \\
\hline SE & & 1.34 & 0.99 & 0.98 \\
\hline Critical q $\mathrm{q}_{0.05, \infty, 4}$ & & 2.35 & 2.35 & 2.35 \\
\hline Actual q & & 4.90 & 6.52 & - \\
\hline
\end{tabular}

\section{DISCUSSION}

\section{Temperature experiments (Expts 1 and 2)}

Monoporeia affinis is a stenotherm, cold-water glacial relict with a previously reported temperature tolerance of $11^{\circ} \mathrm{C}$ in long-term laboratory experiments (Smith 1972) and $14.5^{\circ} \mathrm{C}$ in field observations (Ekman 1915). Segerstråle $(1937,1978)$ reported a much higher temperature tolerance of $22^{\circ} \mathrm{C}$ in short-term experiments and field observations, while earlier work based on field observations reported that reproduction was already inhibited at $7^{\circ} \mathrm{C}$ (Samter \& Weltner 1904).

\section{Effect of increased temperature on reproduction}

In our study, a temperature increase of 3 to $5^{\circ} \mathrm{C}$ did not inhibit, but clearly affected reproduction in Monoporeia affinis. Fertilisation success was affected to a lesser extent in Expt 2, where females were examined in January, than in Expt 1, where females were examined in November. This indicates that mating could be delayed rather than inhibited by increased temperature and that it takes place when the water temperature subsequently falls. Furthermore, there are indications of higher sensitivity during the period of gonad maturation than in the period of embryogenesis. The percentages of dead eggs and females carrying dead broods were higher after pre-mating exposure, while no significant effects were recorded after exposure during embryogenesis.

The correlation between pre-mating exposure and reproductive disorders in terms of unfertilised females and dead broods could be explained by the high temperature-sensitivity of male sperm. In Atlantic salmon Salmo salar, sperm mobility (which is considered to reflect fertilisation ability: Aas et al. 1991), was already affected at temperatures above $4^{\circ} \mathrm{C}$ (Vladic \& Järvi 1997). The temperature sensitivity of male sperm is highly relevant for amphipods, since particularly adult males migrate vertically in the water column during gonad development and mating. This period coincides with the maximum water temperatures in late summer and early autumn (Segerstråle 1937, Donner et al. 1987). At the sampling site the temperature at $30 \mathrm{~m}$ depth and above shows great variation over the year and as late as October temperatures of $11.8^{\circ} \mathrm{C}$ have been registered (SHARK database).

\section{Differences between Monoporeia affinis and Pontoporeia femorata}

Dead eggs occurred more frequently in Monoporeia affinis than in Pontoporeia femorata: the majority of these eggs were undeveloped or unfertilised. P. femorata on the other hand had tended towards a higher proportion of undeveloped or unfertilised eggs. We suggest however that both species were affected in a similar way, the difference being that the dead eggs of $M$. affinis were at a later stage in the process of degeneration than the merely unfertilised/undeveloped eggs of $P$. femorata. The developmental stages of $P$. femorata embryos was also found to be lower than those of M. affinis.

The percentage of malformed embryos was on a par with Baltic background levels, which are 2 to $4 \%$ for Monoporeia affinis and 5 to $10 \%$ for Pontoporeia femorata (Andersson et al. 1999). The reason for the higher malformation rate in $P$. femorata is unclear, but as a marine species living in the Baltic, on the border of its salinity tolerance, its resistance to various stressors may be lowered. Results contradicting our salinity hypothesis were, however, obtained by Johansson 
(1997a), who reported that increased salinity did not increase tolerance to hypoxia in P. femorata.

The greatest dissimilarity between species was the large variation in gonad maturation observed in Pontoporeia femorata regardless of treatment. A large proportion of $P$. femorata specimens deviated from the normal seasonal reproduction cycle. As the reproduction cycle is triggered by the reduction of light after midsummer (Segerstråle 1971), amphipods living at depths where no perception of light is possible sometimes have a more dispersed reproduction period. However, both species in this experiment were collected at the same location at 45 to $50 \mathrm{~m}$ depth, a depth that should not influence the normal reproduction period. P. femorata in abnormal reproductive stages have also been observed in the field (Sundelin et al. 2000). We have no explanation for the dispersed reproduction observed for $P$. femorata. Normally, embryos are hatched in February to March at the time of the spring bloom; hatching in the 'wrong' season could result in juveniles not receiving sufficient and/or high-quality food.

The observed difference in fecundity between these 2 species is in accordance with data from the monitoring programme in the Baltic, where the fecundity of Pontoporeia femorata is lower than that reported for the north-western Atlantic (Steele \& Steele 1978). The reason for this fecundity difference is unclear. Dwelling on the border of its salinity tolerance might be the explanation not only of the high malformation rate but also of the lower fertility rate in $P$. femorata.

\section{Oxygen experiment (Expt 3)}

Most studies concerning benthos and hypoxia focus on lethal oxygen concentrations (Sprague 1963, Gamble 1970, Johansson 1997a). Fewer studies have dealt with sublethal concentrations (Hagerman \& Szaniawska 1986, Breitburg et al. 1994), and even fewer with the sublethal effects of hypoxia on reproduction (Breitburg 1992).

The oxygen concentrations in this experiment were not constant, reflecting the situation in situ. Oxygen concentration varied between 2.5 and $6.6 \mathrm{ml} \mathrm{O}_{2} \mathrm{l}^{-1}$ during September and October 1992-1999 (SHARK database). The oxygen measurements were carried out at $40 \mathrm{~m}$ depth at a station included in the Swedish National Monitoring Programme and situated close to the sampling site of this experiment.

\section{Effects of moderate hypoxia on broods}

The time spent on active brooding increases when oxygen conditions are impaired or when temperature increases. Brooding also increases after gastrulation and decreases at the end of embryogenesis (Dick et al. 1998). In our experiment, low oxygen caused an increased number of dead broods. However, despite increased efforts by the females to oxygenate their broods (i.e. increasing oxygenation by movments of their pleiopods) repeated and/or extended periods of hypoxia may diminish their ability to do this as actively as necessary. This implies that during sensitive parts of the life cycle, temporary hypoxia, which does not affect the adult amphipod, could be lethal do the embryo. Embryonic and larval stages are more sensitive to environmental stressors such as fluctuating hypoxia, temperature and salinity than juveniles (Baker \& Mann 1994, Qiu \& Qian 1998).

\section{Effects of hypoxia on mating and fertilisation}

In the oxygen experiment, the number of fertilised females was lower and the rate of unfertilised females higher in the treatment than in the control group, irrespective of whether solely hypoxia or hypoxia combined with contaminants was tested. Multiple stressors can act either synergistically or antagonistically. The effect of multiple stressors may be other than the sum or product of the individual effect of single factors (Folt et al. 1999). A possible synergistic effect was observed for fecundity in our experiment, as the combination of contaminated sediment and low oxygen reduced fecundity, while none of these factors by itself had any significant effect.

The proportion of malformed eggs was higher in the contaminated sediment series, which agrees with results of Sundelin \& Eriksson (1998). The proportion of unfertilised/undeveloped eggs was higher in the series exposed to moderate hypoxia. The lower number of fertilised females, and possibly also the higher proportion of unfertilised eggs could partly be due to low survival rates of males and possibly also to death of fertilised females. A higher sensitivity to hypoxia of males and egg-bearing females has been observed (Vopel et al. 1998). Moreover, the swimming activity of Monopreia affinis and Pontoporeia femorata, which is strongly connected to the mating process, has been reported to be significantly affected at $3.9 \mathrm{mg} \mathrm{O}_{2} \mathrm{l}^{-1}$ (Johansson 1997b). Non-reproduction has also been observed to be correlated with hypoxia (Trippel \& Harvey 1988).

The variable oxygen situation at coastal stations in the Baltic where hypoxia frequently occurs (Elmgren 1989, Andersson et al. 2000) is stressful for the benthic species. The sensitivity to low oxygen concentrations of Monoporeia affinis is subject to debate; this species has been classified as moderately tolerant to hypoxia 
by Sandberg-Kilpi et al. (1999), while Modig \& Òlafsson (1998) consider it very sensitive. Pontoporeia femorata was reported by Johansson (1997a) to be less tolerant to hypoxia than $M$. affinis. However, when the 2 species co-occur, P. femorata is found deeper in the sediment (Hill \& Elmgren 1987), where the oxygen concentration is generally lower. Lower respiration rates have also been reported for P. femorata (Cederwall 1979), and might be the explanation of the deeper burrowing of this species. It is therefore difficult to make any statement about the sensitivity to hypoxia of $P$. femorata reproduction.

\section{Bioenergetic considerations}

Temperature

Monoporeia affinis $\left(Q_{10}=1.7\right.$ to 2.0; Lehtonen \& Andersin 1998) subjected to increased temperature prior to mating could be at a bioenergetic disadvantage. A rise in temperature of $3.2^{\circ} \mathrm{C}$ would increase the oxygen consumption of this amphipod by approximately 20 to $25 \%$ (Schmidt-Nielsen 1997, p. 218-221), and likewise increase its metabolism. The amphipods used in our experiments store energy in the form of lipids from spring to early autumn. The lipid content of Baltic adult amphipods mainly range from 20 to $40 \%$, depending on season and location (Hill et al. 1992, Lehtonen 1995, 1996). A sufficient amount of stored lipids in relation to size is one of the signals triggering the onset of reproduction (Lehtonen 1996). During autumn and winter, lipids will be relocated to gonads and consumed during reproduction. A rise in temperature increases energy cost and a smaller amount of lipids are available for gonad maturation. Lipid storage in Mysis relicta, for instance, occurs only in colder water (Chess \& Stanford 1999). We argue, therefore, that the reduction in fecundity for females exposed to increased pre-mating temperature in this study is likely to have been a result of increased lipid consumption during gonad development and a subsequent impaired capability to produce eggs.

\section{Hypoxia}

Hypoxia could also increase energetic costs due to a higher respiration rate (Wannamaker \& Rice 2000). In our study the low oxygen concentrations did not cause any considerable effect on fecundity, although hypoxia in combination with contaminants decreased fecundity. Fecundity is also affected by other reproduction disorders. The effects on fecundity caused by dead broods could for instance be difficult to discrim- inate from possible effects of increased energetic cost on gonad development due to higher lipid consumption.

\section{Field and monitoring implications}

Malformed embryos have proved to be a sensitive biomarker in toxicity tests as well as in field studies of industrial recipients, while females carrying dead broods and dead or unfertilised/undeveloped eggs have shown no correlation with contaminant exposure (Sundelin \& Eriksson 1998). The results of the current experiments indicate that the anomalies observed in field-collected amphipods could be explained by hypoxia or increased temperature during critical periods of the reproduction cycle. In the Baltic, gonad maturation occurs during early autumn, a period when moderate hypoxia frequently occurs and elevated temperature occasionally. This could explain our findings.

Our results demonstrate the possibility of separating anomalies caused by contaminants from other types of interference in the field. Most biomarkers for effectmonitoring of contaminants also respond to abiotic variables that vary naturally in the Baltic (e.g. hypoxia and elevated water temperatures). Little effort has been made in studies to examine the sensitivity of biomarkers to these physico-chemical variables, and to separate the effects of contaminants from the effects of other types of stresses. Optimal biomarkers for monitoring contaminants in the field should respond to toxicants but not (or at least only to a lesser extent) to other types of stress. Davis (1993) underlined the urgent need for sensitive early-warning biomarkers with low response to natural climate variables in effect-monitoring of the benthic ecosystem.

In conclusion, for amphipods in the Baltic Sea the most suitable biomarker for effects of increased water temperatures and hypoxia in bottom water and sediments seems to be females carrying dead broods. The proportions of dead or unfertilised/undeveloped eggs are also potential variables in non-contaminant monitoring, although further studies are needed to corroborate these findings.

Acknowledgements. The data from the SHARK database was produced by Dr Ulf Larsson and co-workers, Department of Systems Ecology, Stockholm University, Sweden in the National Swedish and HELCOM monitoring programmes. We also thank Eva Håkansson for sampling and experimental work, Melinda Fones for linguistic revision, Ingela Björck for linguistic revision and valuable comments on the manuscript, and Dr Stig Johan Wiklund for statistical advice. 


\section{LITERATURE CITED}

Aas GH, Refstie T, Gjerde B (1991) Evaluation of milt quality of Atlantic salmon. Aquaculture 95:125-132

Andersson L, Cederwall H, Sundelin B, Eriksson AK (1999) Bottom water and soft bottom fauna. In: Tidlund A (ed) Östersjö 98, Swedish marine monitoring in the Baltic Proper 1998. Stockholm Marine Research Center, Stockholm, p 33-37

Andersson L, Sundelin B, Eriksson Wiklund AK (2000) Bottom water and soft bottom fauna. In: Tidlund A (ed) Östersjö 99, Swedish marine monitoring in the Baltic Proper 1999 Stockholm Marine Research Center, Stockholm, p 23-27

Baker SM, Mann R (1994) Description of metamorphic phases in the oyster Crassostrea virginica and effects of hypoxia on metamorphosis. Mar Ecol Prog Ser 104:91-99

Blomqvist S, Lundgren L (1996) A benthic sled for sampling soft bottoms. Helgol Wiss Meeresunters 50:453-456

Breitburg DL (1992) Episodic hypoxia in Chesapeake Bay: interacting effects of recruitment, behaviour and physical disturbance. Ecol Monogr 62:525-546

Breitburg DL, Steiberg N, DuBeau S, Cooksey C, Houde ED (1994) Effects of low dissolved oxygen on predation of estuarine fish larvae. Mar Ecol Prog Ser 104:235-246

Cederwall H (1978) Long term fluctuations in the macrofauna of northern Baltic soft bottoms. Contrib Askö Lab Univ Stock 22:1-83

Cederwall H (1979) Diurnal oxygen consumption and activity of two Pontoporeia (Amphipoda, Crustacea) species. In: Naylor E, Hartnoll RG (eds) Cyclic phenomena in marine plants and animals. Pergamon Press, Oxford, p 309-316

Chess DW, Stanford J (1999) Experimental effects of temperature and prey assemblage on growth and lipid accumulation by Mysis relicta Loven. Hydrobiologia 412: 155-164

Davis GE (1993) Design elements for monitoring programmes: the necessary ingredients for success. Environ Monit Assess 26: 100-105

Dick JTA, Faloon SE, Elwood RW (1998) Active brood care in an amphipod: influences of embryonic development, temperature and oxygen. Anim Behav 56:663-672

Donner KO, Lindström A, Lindström M (1987) Seasonal variation in the vertical migration of Pontoporeia affinis (Crustacea Amphipoda). Ann Zool Fenn 24:305-313

Ekman S (1915) Die Bodenfauna des Vättern, qualitativ u. quantitativ untersucht. Int Rev Ges Hydrobiol Hydrogr 7: $146-425$

Elmgren R (1989) Man's impact on the ecosystem of the Baltic Sea: energy flows today and at the turn of the century. Ambio 18:326-332

Elmgren R, Hansson S, Larsson U, Sundelin B, Boehm P (1983) The 'Tsesis' oil spill: acute and long term impact on the benthos. Mar Biol 73:51-65

Eriksson AK, Håkansson E, Sundelin B (1999) Vitmärlans embryonalutveckling In: Wiklund K (ed) Gulf of Bottnia 1998. Umeå Marine Research Centre, Umeå, Sweden, p 13-14

Folt CL, Chen CY, Moore MV, Burnaford J (1999) Synergism and antagonism among multiple stressors. Limnol Oceanogr 44:864-877

Gamble JC (1970) Anaerobic survival of crustaceans Corophium volutator, $C$. arenarium and Tanias chevreuxi. Mar Biol Assoc UK 50:657-671

Hagerman L, Szaniawska A (1986) Behaviour, tolerance, ventilation and circulation under hypoxia in the glacial relict Saduria (Mesidotea) entomon. Mar Ecol Prog Ser 34: 125-132
Hill C, Elmgren R (1987) Vertical distribution in the sediment in the co-occurring benthic amphipods Pontoporeia affinis and Pontoporeia femorata. Oikos 49:221-229

Hill C, Quigley MZ, Cavaletto JF, Gordon W (1992) Seasonal changes in lipid content and composition in the benthic amphipods Monoporeia affinis and Pontoporeia femorata. Limnol Oceanogr 37:1280-1289

Ishaq R, Åkerman G, Näf C, Balk L, Bandh C, Broman D (1999) Organic pollutant characterization and toxicity testing of settling particulate matter by nanoinjection in sea trout (Salmo trutta) eggs. Environ Toxicol Chem 18:533-543

Johansson B (1997a) Tolerance of the deposit-feeding amphipods Monopreia affinis and Pontporeia femorata to oxygen deficiency. Mar Ecol Prog Ser 151:135-141

Johansson B (1997b) Behavioural response to gradually declining oxygen concentration by Baltic Sea macrobenthic crustaceans. Mar Biol 129:71-78

Kajrup N (2000) Hydrografi och hydrokemi. In: Wiklund K (ed) Gulf of Bothnia 1999. Umeå Marine Research Center, Umeå, Sweden $\mathrm{p} 7-8$

Lehtonen KK (1995) Geographical variability in the bioenergetic characteristics of Monoporeia/ Pontoporeia spp. population from the northern Baltic Sea and their potential contribution to benthic nitrogen mineralization. Mar Biol 123:555-564

Lehtonen KK (1996) Ecophysiology of the benthic amphipod Monoporeia affinis in an open-sea area of the northern Baltic Sea: seasonal variations in body composition, with bioenergetic considerations. Mar Ecol Prog Ser 143: 87-97

Lehtonen KK, Andersin AB (1998) Population dynamics, response to sedimentation and role in the benthic metabolism of the amphipod Monoporeia affinis in an open-sea area of the northern Baltic Sea. Mar Ecol Prog Ser 168: $71-85$

Lopez G, Elmgren R (1989) Feeding depths and organic absorption for the deposit feeding benthic amphipods Pontoporeia affinis and Pontoporeia femorata. Limnol Oceanogr 34:982-991

Modig M, Olaffson E (1998) Responses of Baltic benthic invertebrates to hypoxic events. J Exp Mar Biol Ecol 229: 133-148

Qiu JW, Qian PY (1998) Combined effects of salinity and temperature on juvenile survival, growth and maturation in the polychaete Hydroide elegans. Mar Ecol Prog Ser 168: 127-134

Samter M, Weltner W (1904) Biologische Eigentümlichkeiten der Mysis relicta, Pallasea quadrispinosa und Pontoporeia affinis, erklärt aus ihrer eiszeitlichen Entstehung. Zool Anz 27:676-694

Sandberg-Kilpi E, Visman B, Hagerman L (1999) Tolerance of the Baltic amphipod Monoporeia affinis to hypoxia, anoxia and hydrogen sulfide. Ophelia 50:61-68

Schmidt-Nielsen K (1997) Animal physiology: adaptation and environment. 5th edn, Cambridge University Press, Cambridge

Segerstråle SG (1937) Studien über die Bodentierwelt in südfinnländischen Küstengewässern. III. Zur Morphologie und Biologie des Amphipoden Pontoporeia affinis, nebst einer Revision der Pontporeia-Systematik. Comment Biol Soc Sci Fenn 7(1):1-183

Segerstråle SG (1971) Light and gonad development in Pontporeia affinis. In: Crisp DJ (ed) Proc 4th Eur Mar Biol Symp. Cambridge University Press, Cambridge, p 573-581

Segerstråle SG (1978) Upper limits of the depth range and temperature tolerance of the Baltic Pontoporeia affinis (Amphipoda, Crustacea) Ann Zool Fenn 15:200-201 
SIS (Swedish Institute for Standards) (1993) Water qualitydetermination of dissolved oxygen-iodometric method (SS-EN 25813). SIS, Stockholm, Sweden

SIS (Swedish Institute for Standards) (1993) Water qualitydetermination of dissolved oxygen-electrochemical probe method (SS-EN 25814). SIS, Stockholm, Sweden

Smith WE (1972) Culture, reproduction and temperature tolerance of Pontoporeia affinis in the laboratory. Trans Am Fish Soc 101:253-256

Sprague JB (1963) Resistance of four freshwater crustaceans to lethal high temperature and low oxygen. J Fish Res Board Can 20:387-415

Steele DH, Steele VJ (1978) Some aspects of the biology of Pontoporeia femorata and Pontoporeia affinis (Crustacea, Amphipoda) in the north-western Atlantic. Astarte 11:61-66

Sundelin B (1983) Effects of cadmium on Pontoporeia affinis (Crustacea: Amphipoda) in laboratory soft-bottom microcosms. Mar Biol 74:203-212

Sundelin B, Eriksson AK (1998) Malformations in embryos of the deposit-feeding amphipod Monoporeia affinis in the Baltic Sea. Mar Ecol Prog Ser 171:165-180

Sundelin B, Eriksson AK (2001) Mobility and bioavailability of

Editorial responsibility: Otto Kinne (Editor),

Oldendorf/Luhe, Germany trace metals in sulfidic coastal sediments. Environ Toxicol Chem 20:(4)748-756

Sundelin B, Ryk C, Malmberg G (2001) Effects on the sexual maturation of the sediment living amphipod Monoporeia affinis. Environ Toxicol 15:(5)518-526

Trippel EA, Harvey HH (1988) Missing opportunities to reproduce: an energy dependent or fecundity gaining strategy in white sucker (Catostomus commersoni). Can J Zool 67: $2180-2188$

Vladic T, Järvi T (1997) Sperm motility and the fertilization time span in Atlantic salmon and brown trout - the effect of water temperature. J Fish Biol 50:1088-1093

Vopel K, Dehmlow J, Johansson M, Arlt G (1998) Effects of anoxia and sulphide on populations of Cletocamptus confluens (Copepoda, Harpacticoida). Mar Ecol Prog Ser 175: 121-128

Wannamaker CM, Rice JA (2000) Effects of hypoxia on movements and behaviour of selected estuarine organisms from the southeastern United States. J Exp Mar Biol Ecol 249: $145-163$

Zar JH (1984) Biostatistical analyses, 2nd edn. Prentice-Hall, Englewood Cliffs, NJ

Submitted: July 12, 2000; Accepted: January 15, 2001

Proofs received from author(s): October 26, 2001 